\title{
The increased angiotensin II (type 1) receptor density in myocardium of type 2 diabetic patients is prevented by blockade of the renin-angiotensin system
}

\author{
H. Reuter • C. Adam • S. Grönke • C. Zobel • \\ K. F. Frank • J. Müller-Ehmsen • J. Brabender • \\ R. H. G. Schwinger
}

Received: 28 June 2006 / Accepted: 31 July 2006 / Published online: 19 October 2006

(C) Springer-Verlag 2006

\begin{abstract}
Aims/hypothesis The angiotensin II (type 1) (AT1) receptor mediates many biological effects of the renin-angiotensin system (RAS), leading to remodelling of cardiac tissue. The present study was designed to analyse changes in the function and expression of the AT1 receptor as principal effector of the RAS in myocardium from type 2 diabetic patients compared with non-diabetic myocardium as control. In addition, we determined the effect of treatment with ACE inhibitors or AT1 receptor blockers on expression levels of the receptor in diabetic patients.

Methods Gene expression of the AT1 receptor was analysed by quantitative RT-PCR and protein expression was determined by immunoblot analysis in human right atrial myocardium. We investigated functional coupling of the receptors by measuring contractility in isolated trabeculae stimulated with increasing concentrations of angiotensin II. Results Diabetic myocardium showed a significant increase in protein expression $(170 \pm 16 \%$ of control) and median mRNA expression (186\% of control) of the AT1 receptor.
\end{abstract}

H. Reuter $(\bowtie) \cdot$ C. Adam · S. Grönke · C. Zobel • K. F. Frank

J. Müller-Ehmsen

Laboratory of Muscle Research and Molecular Cardiology,

Department III of Internal Medicine, University of Cologne,

Joseph-Stelzmann-Str. 9,

50924 Cologne, Germany

e-mail: Hannes.Reuter@koeln.de

J. Brabender

Department of Visceral and Vascular Surgery,

University of Cologne,

Cologne, Germany

R. H. G. Schwinger

Medical Clinic II, Klinikum Weiden,

Weiden i. OPf., Germany
The additional receptors were functionally coupled, resulting in a stronger inotropic response upon stimulation with angiotensin II ( $89 \pm 5.5 \%$ vs $29 \pm 1.6 \%$ in controls), whereas receptor affinity was similar in both groups. However, myocardium from diabetic patients treated with ACE inhibitors or AT1 receptor blockers showed no increase in AT1 receptor expression.

Conclusions/interpretation AT1 receptor expression in myocardium of type 2 diabetic patients is dynamic, depending on the level of glycaemic control and the activity of the RAS. These findings could at least in part explain the strong therapeutic benefit of RAS inhibition in diabetic patients.

Keywords ACE inhibitors · Angiotensin II .

AT1 receptor blockers - AT1 receptors · Contractility .

Human myocardium - Type 2 diabetes
Abbreviations
AT1 angiotensin II (type 1)
FOC force of contraction
PKC protein kinase $\mathrm{C}$
RAS renin-angiotensin system
$+T$ peak rate of tension increase
$-T$ peak rate of tension decay

\section{Introduction}

The common characteristic of diabetes mellitus is hyperglycaemia. However, the aetiology of the disease can differ substantially. The predominant type 2 diabetes affects $95 \%$ of diabetic patients and is commonly associated with other metabolic disorders like obesity, hyperlipidaemia and 
hypertension. Type 2 diabetes is characterised by an insulin-resistant state with a defective cellular response to the high serum levels of glucose and insulin. In contrast, type 1 diabetic individuals (the remaining 5\%) typically show no signs of metabolic syndrome and have low levels of insulin due to the destruction of pancreatic beta cells. Both, glucose and insulin have been implicated in gene regulation that may promote the development of cardiovascular disease in diabetic patients $[1,2]$.

The renin-angiotensin system (RAS), and especially the angiotensin II (type 1) (AT1) receptor, has been implicated in the cardiovascular pathophysiology of diabetes. Angiotensin II, the principal effector of the RAS, is a myocardial growth factor and an independent risk factor for cardiovascular disease [3]. Angiotensin II may account for enhanced release of free radicals, induces vasoconstriction and may also be involved in cell proliferation and fatty streak formation via AT1 receptor activation [4]. There is a broad body of evidence that AT1 receptor signalling also promotes cardiovascular complications in patients with diabetes and is probably involved in the pathogenesis of diabetic cardiomyopathy and coronary artery disease, by far the leading cause of death in the diabetic population [5]. Accordingly, major clinical trials in patients with type 2 diabetes and hypertension have provided evidence that blockade of the RAS by the use of ACE inhibitors or AT1 receptor antagonists may be superior to alternative antihypertensive agents in the prevention of cardiovascular events, independently of their antihypertensive potency [6-9].
The present study was therefore designed to evaluate, in non-failing myocardium of type 2 diabetic patients, the changes in AT1 receptor density and function that could account for the beneficial effects of RAS inhibition.

\section{Subjects and methods}

\section{Patients}

Human right atrial tissue was obtained from patients suffering from type 2 diabetes mellitus and from nondiabetic individuals as control, all of whom were undergoing aortocoronary bypass surgery without signs of cardiac failure as determined by echocardiography. In addition, a subgroup of diabetic patients receiving long-term treatment with ACE inhibitors or AT1 receptor blockers was analysed to determine the effect of RAS blockade on AT1 receptor expression. Glucose metabolism was monitored by measuring serum levels of fasting glucose on three consecutive days, as well as by determination of $\mathrm{HbA}_{1 \mathrm{c}}$ on the day before surgery. Patients were carefully selected to avoid differences in the distribution of cardiovascular risk factors, in mean arterial blood pressure, or in the long-term medical treatment among groups (Table 1). Drugs used for general anaesthesia were flunitrazepam, fentanyl and pancuronium bromide with isoflurane. The study was performed in accordance with the principles of the Declaration of Helsinki as revised in 2000 and was approved by the ethics

Table 1 Clinical and biochemical characteristics of participants

\begin{tabular}{|c|c|c|c|}
\hline Characteristics & Control $(n=7)$ & Diabetes $(n=7)$ & Therapy $(n=7)$ \\
\hline \multicolumn{4}{|l|}{ Clinical characteristics } \\
\hline Age (years) & $63.9 \pm 1.3$ & $65.6 \pm 4.3$ & $62.6 \pm 4.0$ \\
\hline Sex (men/women) & $6 / 1$ & $6 / 1$ & $6 / 1$ \\
\hline BMI $\left(\mathrm{kg} / \mathrm{m}^{2}\right)$ & $24.9 \pm 0.7$ & $29.4 \pm 2.9 *$ & $28.0 \pm 0.9 *$ \\
\hline Mean systolic blood pressure (mmHg) & $120.5 \pm 2.7$ & $127.6 \pm 5.6$ & $122.9 \pm 5.0$ \\
\hline Mean diastolic blood pressure $(\mathrm{mmHg})$ & $68.5 \pm 1.8$ & $77.6 \pm 2.5 *$ & $70.9 \pm 0.6$ \\
\hline $\mathrm{HbA}_{1 \mathrm{c}}(\%)$ & $5.3 \pm 0.2$ & $8.2 \pm 0.6 *$ & $7.9 \pm 0.7 *$ \\
\hline BNP (ng/l) & $429 \pm 208$ & $367 \pm 95$ & $454 \pm 68$ \\
\hline Serum creatinine $(\mu \mathrm{mol} / \mathrm{l})$ & $79.6 \pm 3.5$ & $88.4 \pm 5.3$ & $97.2 \pm 15.0$ \\
\hline Serum cholesterol (mmol/l) & $4.8 \pm 0.6$ & $3.8 \pm 0.3$ & $5.7 \pm 0.6$ \\
\hline Current smoker & 1 & 3 & 4 \\
\hline \multicolumn{4}{|l|}{ Hyperglycaemic control } \\
\hline Dietary therapy alone & - & 3 & 3 \\
\hline Oral agents alone & - & 4 & 4 \\
\hline \multicolumn{4}{|l|}{ Other drugs } \\
\hline ACE inhibitor/AT1 blocker & 0 & 0 & 7 \\
\hline Diuretics & 2 & 2 & 5 \\
\hline Beta-blockers & 4 & 5 & 4 \\
\hline Calcium channel blockers & 1 & 0 & 0 \\
\hline Statins & 1 & 2 & 4 \\
\hline
\end{tabular}

Smokers and patients taking the respective drugs/treatments are listed in absolute numbers, all other values are given as mean \pm SEM. $* p<0.05$ vs non-diabetic controls. BNP B-type natriuretic peptide 
committee of the University of Cologne. Patients gave written informed consent before the operation.

Measurement of force of contraction

From the myocardial tissue sample, auricular trabeculae 0.6 to $0.8 \mathrm{~mm}$ wide and 6 to $8 \mathrm{~mm}$ long were prepared under microscopic observation. The preparations were attached to a bipolar platinum stimulating electrode and suspended individually in $75-\mathrm{ml}$ glass tissue chambers for recording of isometric contractions. The bathing solution used was a modified Tyrode's solution containing in mmol/l: $\mathrm{NaCl}$ 119.8, $\mathrm{KCl}$ 5.4, $\mathrm{CaCl}_{2}$ 1.8, $\mathrm{MgCl}_{2}$ 1.05, $\mathrm{NaH}_{2} \mathrm{PO}_{4}$ 0.42, $\mathrm{NaHCO}_{3} 22.6, \mathrm{Na}_{2}$ EDTA 0.05 , ascorbic acid 0.28 , glucose 5.0. It was continuously gassed with $95 \% \mathrm{O}_{2}$ and $5 \% \mathrm{CO}_{2}$ $\left(37^{\circ} \mathrm{C}, \mathrm{pH} 7.4\right)$. The preparations were electrically paced with rectangular pulses of $5 \mathrm{~ms}$ duration at $1 \mathrm{~Hz}$; the voltage was $20 \%$ above threshold. All preparations were allowed to equilibrate for at least $90 \mathrm{~min}$ in a drug-free bathing solution until complete mechanical stabilisation. The isometric force of contraction (FOC) was measured with an inductive force transducer (W. Fleck, Mainz, Germany) attached to a recording device (Helco Scriptor; Hellige, Freiburg, Germany) or recorder (Gould, Cleveland, $\mathrm{OH}$, USA). Experiments were performed as described previously [10].

\section{Western blot analysis}

Homogenates of atrial tissue were suspended in SDS sample buffer containing $0.5 \mathrm{mmol} / \mathrm{l}$ Tris- $\mathrm{HCl}, 10 \%$ glycerol, 2\% SDS, 5\% 2-mercaptoethanol, and $0.05 \%$ bromophenol blue, and heated in boiling water for $5 \mathrm{~min}$. Equal amounts of protein $(30 \mu \mathrm{g}$ total protein) from all samples were separated on $12 \%$ SDS-polyacrylamide gels and transferred on to a polyvinylidene difluoride membrane (Bio-Rad Laboratories, Hercules, CA, USA) overnight. The blots were probed with an AT1 receptor-specific rabbit polyclonal antibody against the $\mathrm{N}$-terminal extracellular domain of the AT1 receptor of human origin $\left(\mathrm{AT}_{1}[\mathrm{~N}-10]\right.$ : sc-1173; Santa Cruz Biotechnology, Santa Cruz, CA, USA) or polyclonal rabbit antibodies against canine calsequestrin (Swant, Bellinzona, Switzerland). Immunodetection was conducted with a goat anti-rabbit secondary antibody for $30 \mathrm{~min}$ at $24^{\circ} \mathrm{C}$ (1:5000 dilution; Sigma Chemical, St Louis, MO, USA) and visualised by chemoluminescence (Amersham, Bucks, UK). The linearity of the assay was confirmed in separate experiments.

mRNA isolation

Total RNA was isolated by a single-step guanidinium isothiocyanate method using a micro mRNA purification kit (QuickPrep; Amersham Pharmacia Biotech, Piscataway, NJ, USA) according to the manufacturer's instructions. After RNA isolation, cDNA was prepared from each sample as previously described [11].

Real-time RT-PCR quantification

cDNAs and an internal reference gene ( $\beta$-actin) were quantified using a fluorescence-based real-time detection method (ABI PRISM 7700 Sequence Detection System [TaqMan]; Perkin-Elmer Applied Biosystems, Foster City, CA, USA) as described previously [12]. The PCR reaction mixture consisted of $600 \mathrm{nmol} / \mathrm{l}$ each of the primers, $200 \mathrm{nmol} / \mathrm{l}$ probe, 2.5 units of AmpliTaq Gold Polymerase, $200 \mu \mathrm{mol} / \mathrm{l}$ each of dATP, dCTP and dGTP, $400 \mu \mathrm{mol} / 1$ dUTP, $5.5 \mathrm{mmol} / 1 \mathrm{MgCl}_{2}$, a $1 \times$ TaqMan buffer A containing a reference dye, prepared to a final volume of $25 \mu \mathrm{l}$ (all reagents from Perkin-Elmer Applied Biosystems). Cycling conditions were $50^{\circ} \mathrm{C}$ for $10 \mathrm{~s}, 95^{\circ} \mathrm{C}$ for $10 \mathrm{~min}$, followed by 46 cycles at $95^{\circ} \mathrm{C}$ for $15 \mathrm{~s}$ and at $60^{\circ} \mathrm{C}$ for $1 \mathrm{~min}$. The primers and probe sequences for $\beta$-actin were as follows: primers, 5'-TGAGCGCGGCTACAGCTT-3' and 5' TCCTTAATGTCACGCACGATTT-3'; probe, 6-carboxyfluorescein-5'-ACCACCACGGCCGAGCGG-3'- $N, N, N^{\prime}$, $N^{\prime}$-tetramethyl-6-carboxyrhodamine. PCR primers and fluorogenic probes for the AT1 receptor cDNA were purchased as assay-on-demand (Assay ID-no. Hs00241341_m1; Applied Biosystems, Foster City, CA, USA); this generates an amplicon of 144 base pairs.

For each sample, parallel TaqMan PCR reactions were performed for the AT1 receptor gene and the $\beta$-actin reference gene to normalise for input cDNA. The ratio between the values obtained provided relative gene expression levels for the gene locus investigated.

Statistical analysis

Protein expression of the AT1 receptor was normalised to calsequestrin expression as an internal protein standard and expressed as AT1 receptor to calsequestrin ratio. Differences between groups were compared with two-way ANOVA. TaqMan analyses yield values that are expressed as ratios between two absolute measurements (gene of interest/internal reference gene). The Kruskal-Wallis test was used to identify significant differences in expression between the three groups. When the overall Kruskal-Wallis test (comparing the three groups) was significant at the 0.05 level, pairwise comparisons were based on the MannWhitney test and the nominal $p$ value was reported. Associations between two related variables were tested by Wilcoxon signed rank test. Linear regression data analysis was determined using PRISM software (Graphpad Software, San Diego, CA, USA). The inotropic effect of 
angiotensin II in each muscle strip was compared with the drug-free situation of the very same preparation. The level of significance was set at $p<0.05$. All $p$ values reported were based on two-sided tests.

\section{Results}

The percentage of $\mathrm{HbA}_{1 \mathrm{c}}$ is a serum marker correlating with the average glucose level over the previous 3 months and confirmed the poor metabolic control of diabetic patients enrolled in the present study (Table 1). Diabetes is a strong risk factor for cardiovascular disease including heart failure $[13,14]$. For our patients contractile dysfunction was ruled out by echocardiography. This was further supported by the almost identical serum levels of B-type natriuretic peptide, a neurohormone that serves as a diagnostic and prognostic marker of heart failure (Table 1). In accordance with these in vivo data, we found no difference in the basal FOC or other characteristics of development and decay of isometric force in isolated atrial muscle strips from diabetic and non-diabetic individuals. Table 2 summarises some characteristics of the contractionrelaxation cycle in human atrial preparations paced at $1 \mathrm{~Hz}$. Angiotensin II is known to be a strong positive inotropic agent in atrial and ventricular myocardium of different species [15-17]. The increase in FOC is mainly attributed to stimulation of the L-type $\mathrm{Ca}^{2+}$ current secondary to activation of protein kinase C (PKC) [18, 19]. Accordingly, upon stimulation with angiotensin II, we recorded a concentration-dependent increase in FOC in myocardium both from diabetic and from non-diabetic patients. With an increase on average of $29 \pm 1.6 \%$, the maximal inotropic potency of angiotensin II in atrial preparations of nondiabetic individuals was comparable with previous studies [17]. However, atrial trabeculae from diabetic patients showed a stronger response to angiotensin II with a maximal increase on average of $89 \pm 5.5 \%(p<0.05$ vs control; Fig. 1a). Despite this difference in the maximal response to angiotensin II, there was no change in the sensitivity of myocardium in either group to the substance ( $\mathrm{IC}_{50}$, control: $1.9 \times 10^{-8}$, diabetes: $8.9 \times 10^{-9}$; NS; Fig. $1 \mathrm{~b}$ ).
Angiotensin II also had a negative lusitropic effect on human right atrial myocardium with a prolonged time to half-peak relaxation in both groups and an increase in the ratio of the peak rate of tension increase and tension decay $(+T /-T)$. The increase in $+T /-T$ however only reached statistical significance in diabetic myocardium (Table 2). The maximal inotropic response to excessive doses of extracellular calcium in both groups was similar (FOC [15 mmol/ $/ \mathrm{Ca}^{2+}$ ] control: $10.6 \pm 1.7 \mathrm{mN}$, diabetes: $8.8 \pm$ $1.5 \mathrm{mN}$; NS) indicating that inotropic potency remained unchanged.

The positive inotropic effects of angiotensin II are mediated by the AT1 receptor. We therefore determined the levels of gene expression and protein expression of the AT1 receptor in atrial myocardium from non-diabetic and diabetic patients as a potential molecular correlate for the different inotropic response to angiotensin II. In addition, we determined the effect of long-term RAS blockade therapy on expression levels of the receptor in diabetic patients. AT1 receptor mRNA expression was detectable by quantitative real-time PCR in all specimens of the three groups. The median AT1 receptor mRNA expression in relation to the internal reference gene $\beta$-actin was: 9.0 (range 4.3-30.1) in diabetes, 4.8 (range 0.7-17.2) in controls ( $p=0.01$ vs diabetes) and 4.1 (range 2.8-13.2) in diabetes with therapy ( $p=0.001$ vs diabetes) (Fig. 2). The level of expression of AT1 receptor mRNA in diabetic patients showed a linear correlation $\left(r^{2}=0.80\right.$; slope $0.156 \pm$ 0.034 ; $p=0.006$; Fig. 3 ) with the percentage level of $\mathrm{HbA}_{1 \mathrm{c}}$ in the serum, which serves as a marker for quality of glycaemic control. There was no correlation of AT1 receptor mRNA with other clinical characteristics or with drug therapy in the individual groups. In line with the elevated levels of receptor mRNA, western blot analysis showed that protein expression of the AT1 receptor was increased by $70 \pm 16 \%$ in diabetic myocardium compared with control. However, the densities of the AT1 receptor between myocardium from non-diabetic patients and diabetic patients with therapy were unchanged. Representative blots and summary data from seven individuals in each group are shown in Fig. 4a,b.

Table 2 Characteristics of the contraction-relaxation cycle in human atrial muscle strips paced at $1 \mathrm{~Hz}$

\begin{tabular}{|c|c|c|c|c|c|c|}
\hline & FOC $(\mathrm{mN})$ & $+T(\mathrm{mN} / \mathrm{s})$ & $-T(\mathrm{mN} / \mathrm{s})$ & $+T /-T$ & $T_{1 / 2} T(\mathrm{~ms})$ & $T_{\text {twitch }}(\mathrm{ms})$ \\
\hline $\mathrm{ND}(n=7)$ & $3.68 \pm 0.7$ & $35.7 \pm 6.8$ & $28.9 \pm 5.3$ & $1.23 \pm 0.03$ & $75.0 \pm 1.5$ & $447 \pm 11$ \\
\hline $\mathrm{ND}+$ Ang II & $4.48 \pm 0.7 * *$ & $51.2 \pm 7.4 * *$ & $40.3 \pm 6.4 * *$ & $1.29 \pm 0.04$ & $79.3 \pm 1.7 * *$ & $465 \pm 12$ \\
\hline $\mathrm{DM}(n=7)$ & $2.81 \pm 0.9$ & $39.7 \pm 7.1$ & $31.8 \pm 5.5$ & $1.24 \pm 0.03$ & $70.7 \pm 2.3$ & $432 \pm 21$ \\
\hline $\mathrm{DM}+$ Ang II & $4.94 \pm 1.5 *$ & $53.6 \pm 9.4 *$ & $39.6 \pm 6.1 *$ & $1.34 \pm 0.04 *$ & $76.4 \pm 3.9 *$ & $422 \pm 13$ \\
\hline
\end{tabular}

Data are mean \pm SEM for non-diabetic (ND) and diabetic (DM) myocardium under control conditions and upon addition of angiotensin II (Ang II, $100 \mathrm{nmol} / \mathrm{l})$. FOC force of contraction; $+T$, peak rate of tension increase; $-T$ peak rate for tension decay; $T_{1 / 2} T$, time to half-peak relaxation; $T_{\text {twitch }}$ duration of isometric twitch. ${ }^{*} p<0.05$ vs DM; ${ }^{* *} p<0.05$ vs ND 


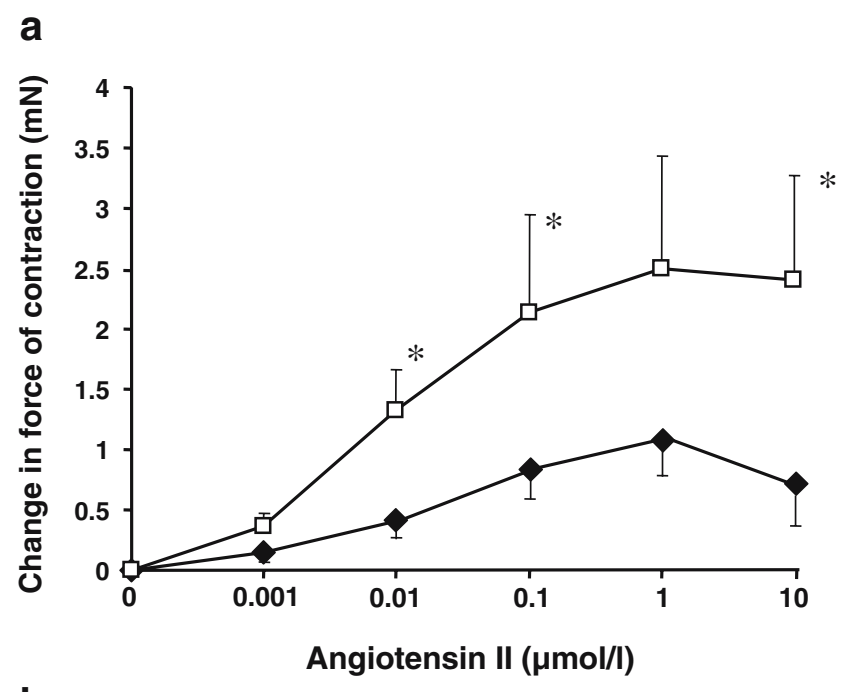

b

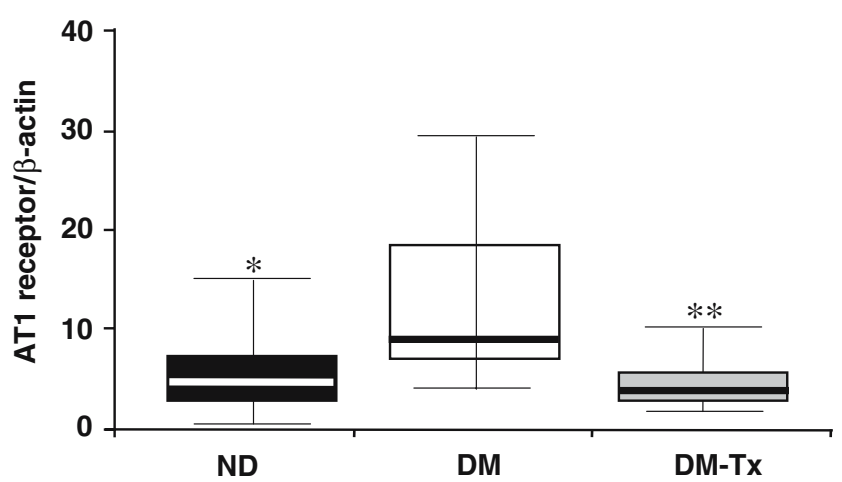

Fig. 2 Box and whisker plots of relative AT1 receptor mRNA expression determined by quantitative real-time RT-PCR in myocardium from non-diabetic patients (ND), diabetic patients (DM) and diabetic patients receiving ACE inhibitors or AT1 receptor blockers (DM-Tx). The boxes show the 25th and 75th percentile (interquartile) ranges. Median values are shown as a horizontal bar within each box. The whiskers show levels outside the 25 th and 75 th percentiles. AT1 receptor mRNA expression was significantly enhanced in diabetic myocardium. However, this difference could not be detected in diabetic tissue from patients treated with ACE inhibitors or AT1 receptor blockers. ${ }^{*} p=0.01$ vs $\mathrm{DM} ;{ }^{* *} p=0.001$ vs $\mathrm{DM}$

been reported in diseases like thyroid dysfunction, hypertension and myocardial infarction [22-24]. Our present findings demonstrate increased densities of the AT1 receptor mRNA and protein in human atrial myocardium of patients suffering from type 2 diabetes. These additional receptors are functionally coupled, resulting in a stronger positive inotropic response to stimulation with angiotensin II. However, the increase in AT1 receptor expression in type 2 diabetic patients could be prevented by long-term treatment with ACE inhibitors or AT1 receptor blockers. The patients included in the present study were carefully selected with regard to differences in

Fig. 1 Concentration-dependent positive inotropic effect of angioten$\sin$ II in isolated human atrial trabeculae of diabetic (open squares; $n=$ 7 from five hearts) and non-diabetic (filled diamonds; $n=7$ from six hearts) individuals. Myocardium of diabetic patients showed a significantly stronger inotropic response to angiotensin II (a). However, there was no shift in the $\mathrm{EC}_{50}$ (b), indicating that the affinity of the receptor to angiotensin II was unaltered. ${ }^{*} p<0.05$ vs non-diabetic myocardium

\section{Discussion}

The AT1 receptor mediates many biological effects of the RAS leading to the remodelling of cardiac tissue, including cell growth and the deposition of extracellular matrix proteins $[20,21]$. It also mediates the positive inotropic effects of angiotensin II in cardiac tissue. Thus, the number of AT1 receptors defines the biological efficacy of angiotensin II. The RAS has also been implicated in cardiovascular pathology, and the upregulation of AT1 receptors in the cardiovascular system has

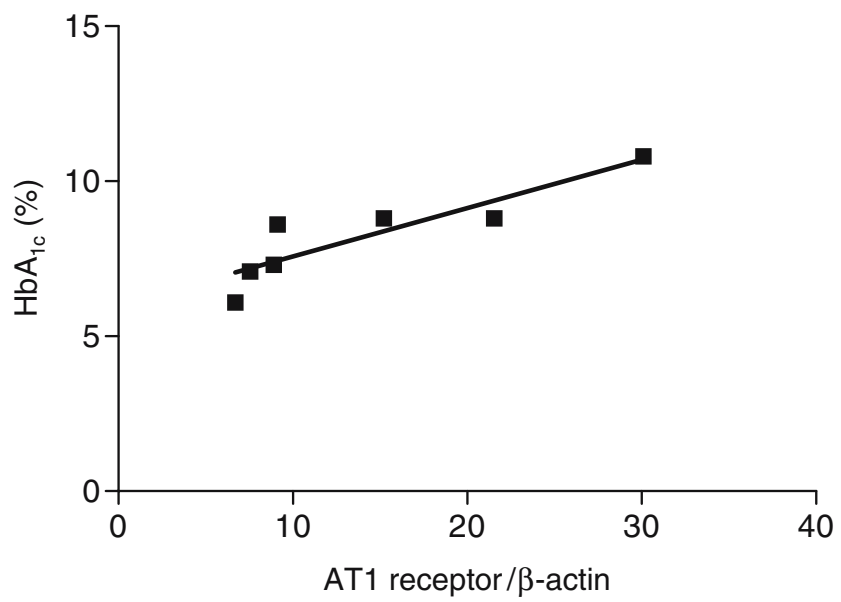

Fig. 3 Relationship between the percentage level of $\mathrm{HbA}_{1 \mathrm{c}}$ and the AT1 receptor mRNA expression in individual diabetic patients (filled squares). There was a linear correlation showing higher levels of mRNA expression in myocardial tissue of patients with poor glycaemic control. Gene expression is given in arbitrary units, normalised by $\beta$-actin expression 
a
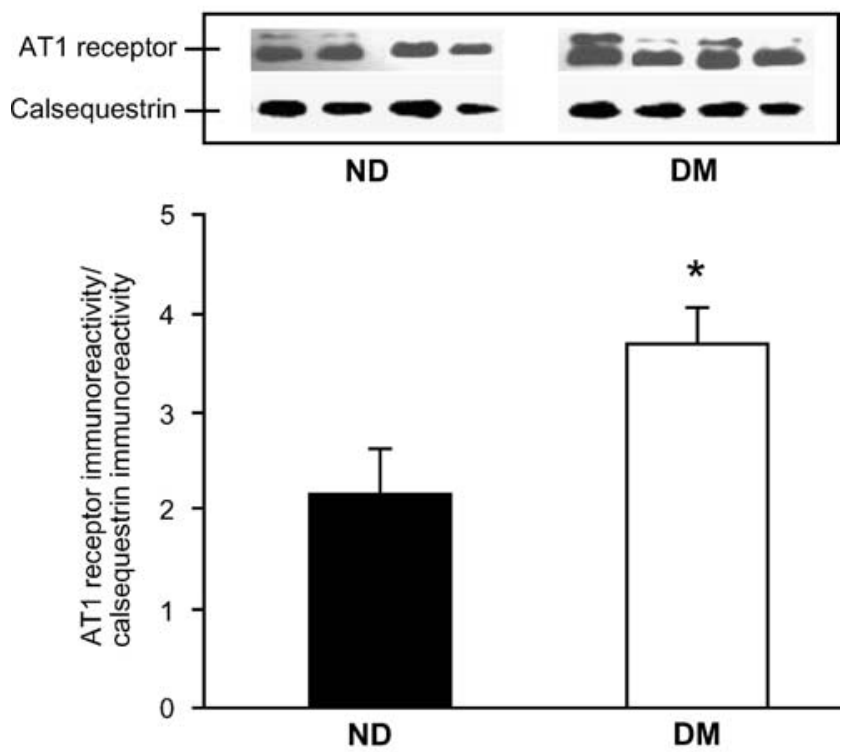

b
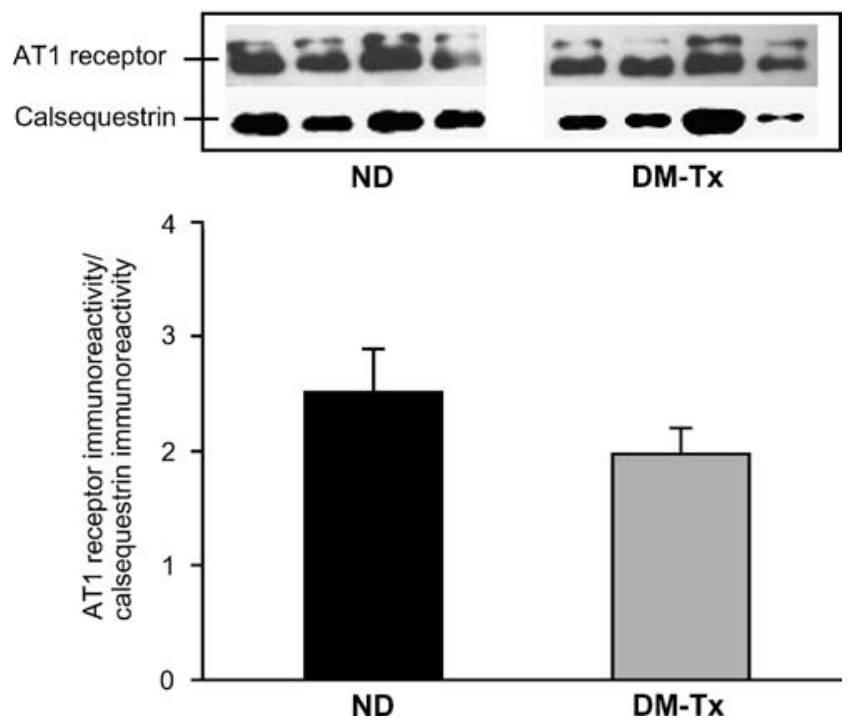

Fig. 4 Immunoreactivity of the AT1 receptor protein and calsequestrin in non-failing human right atrial myocardium. The blots were reacted with a polyclonal antibody against the AT1 receptor and a polyclonal antibody against calsequestrin as an internal protein standard. a Protein expression of the AT1 receptor was increased by $70 \%$ in myocardium of diabetic patients $(\mathrm{DM}, n=7)$ compared with atrial tissue from non-diabetic individuals (ND, $n=7)$. b In myocardium from diabetic patients receiving ACE inhibitors or AT1 receptor blockers (DM-Tx, $n=7)$ no difference in AT1 receptor protein expression from ND could be detected. In each panel the blots are representative of two individual experiments. ${ }^{*} p<0.05$ vs ND

blood pressure and their medical treatment with beta blockers and statins, since all of these factors may influence gene expression [25-27].

Stimulation with angiotensin II had a positive inotropic, but also negative lusitropic effect on human right atrial myocardium. This prolonged relaxation was equally present in myocardium from diabetic and non-diabetic patients. The positive inotropic action of angiotensin II is mainly attributed to an enhancement of the L-type $\mathrm{Ca}^{2+}$ current, secondary to the activation of $\mathrm{PKC}$, and is probably independent of changes in $\mathrm{pH}_{\mathrm{i}}$ or changes in myofilament responsiveness to $\mathrm{Ca}^{2+}[18,19]$. The negative lusitropic action of angiotensin II has been well described in cat ventricular myocardium [19]. The investigators found that this effect was also PKC dependent, and suggested that the mechanism primarily relies on a decrease in $\mathrm{Ca}^{2+}$ efflux through the $\mathrm{Na}^{+}-\mathrm{Ca}^{2+}$ exchanger produced by a prolonged duration of the action potential. It is generally accepted that angiotensin II stimulation of the heart in vivo is largely dependent on high concentrations of angiotensin II produced by the local RAS. This may be one of the reasons why concentrations of angiotensin II used in the present and in previous studies for the stimulation of cardiac tissue in vitro [17-19] are significantly higher than the angiotensin II concentrations present in plasma.

The affinity of the AT1 receptor to angiotensin II in diabetic and non-diabetic myocardium was unaltered, indicating that the receptor itself is unlikely to be the primary cause for the different inotropic response to angiotensin II. However, AT1 receptor densities were increased in right atrial myocardium from type 2 diabetic individuals, as evidenced by immunoblot analysis. This finding was supported by the increased levels of AT1 receptor mRNA, which we detected in the same diabetic tissue by quantitative real-time RT-PCR. These data suggest that overexpression of the AT1 receptor in type 2 diabetes is either the result of enhanced gene expression or stabilisation of receptor mRNA. In the literature there are competing theories about the underlying molecular mechanisms by which AT1 receptor expression may be upregulated in diabetic individuals, including transcriptional and post-transcriptional pathways. Among other stimuli, growth factors, progesterone, lipoproteins and insulin have been proposed to be involved in the regulation of AT1 receptor expression, and numerous consensus sequences were discovered within the promotor region of the AT1 receptor gene, including response elements for oestrogen, cyclic $\mathrm{AMP}$ or nuclear factor- $\mathrm{kB}$ [28]. However, the exact mechanisms of transcriptional control of AT1 receptor mRNA synthesis are still poorly understood.

Type 2 diabetes is characterised by an insulin-resistant state, in which hyperglycaemia is present despite high levels of insulin. In cultured vascular smooth muscle cells both high glucose as well as insulin induced an upregulation of AT1 receptor expression [1, 29]. The pathway for the insulin-driven upregulation of the AT1 receptor is dependent on tyrosine kinases and presumably involves the p42/44 mitogen-activated protein kinase, suggesting in this case a post-transcriptional regulation of receptor expression. Nickenig and co-workers found no influence 
of insulin on AT1 receptor gene expression, but showed a prolonged mRNA half-life, indicating that overexpression of the receptor may be caused by stabilisation of AT1 receptor mRNA [1]. In the present study, levels of AT1 receptor mRNA correlated well with the percentage levels of $\mathrm{HbA}_{1 \mathrm{c}}$ in the serum of diabetic patients (Fig. 3), indicating that the level of hyperglycaemia may play a role in the regulation of AT1 receptor expression in human atrial myocardium. Further studies will be required to determine the exact mechanisms of transcriptional and post-transcriptional control of AT1 receptor expression in diabetes.

Our data on type 2 diabetes in man expand previous observations from animal models of type 1 diabetes induced by treatment with streptozotocin. In the streptozotocin model of diabetes a tissue-specific differential regulation of the AT receptors has been demonstrated with increased levels of AT1 receptor protein and mRNA in cardiovascular tissue $[30,31]$. The AT1 receptor mediates many cellular effects involved in the pathology of fibrosis, hypertension and arteriosclerosis [4], disease states with a high prevalence in the diabetic population. However, there has so far been no indication that the circulating RAS enhances stimulation of AT1 receptors. In the model of streptozotocin-induced diabetes, mRNA levels of cardiac angiotensinogen [30] and plasma levels of angiotensin II [32] and renin, as well as ACE activity [33], were unaltered. In patients with type 2 diabetes, plasma renin activity was even depressed [34] suggesting a predominant regulation by locally produced angiotensin II.

Continuous stimulation of G-protein-coupled receptors frequently results in tachyphylaxis following the downregulation of receptor numbers on the cell surface. For the AT1 receptor a transient downregulation of mRNA levels upon prolonged stimulation with angiotensin II has been described in vitro in isolated rat aortic vascular smooth muscle cells $[35,36]$ and in cultured glomerular mesangial cells [37]. Our data on freshly dissected human myocardium, however, suggest a different regulation of AT1 receptor expression. In the present study, myocardial samples from diabetic patients had increased levels of AT1 receptor mRNA and protein, and also showed an enhanced inotropic response to stimulation with angiotensin II. On the other hand, mRNA and protein densities of the receptor were unchanged in heart tissue from diabetic patients who were being treated with ACE inhibitors or AT1 receptor blockers compared with non-diabetic controls, indicating that the level of AT1 receptor expression in the heart correlates with the activity of the RAS. This finding is supported by other in vivo studies. In a previous work on spontaneously hypertensive rats, Suzuki and co-workers [38] found increased levels of AT1 receptors in this model of cardiac hypertrophy. Normalisation of blood pressure with AT1 receptor blockers regressed cardiac hypertrophy and com- pletely reversed the increase in receptor message and density. In the adrenal gland, Iwai et al. [39] confirmed this relationship between AT1 receptor expression and RAS activity, showing that administration of AT1 receptor blockers reduced the level of AT1 receptor mRNA, whereas the prolonged infusion of angiotensin II increased the expression level of this receptor mRNA.

There are two caveats. First, we cannot rule out that partial internalisation of the receptor protein may influence the present results. Two, the data were obtained using human atrial myocardium. However, human ventricular myocardium does not show any inotropic response to stimulation with exogenous angiotensin I or II [17].

In summary, the present data provide evidence that human atrial myocardium of type 2 diabetic patients has increased densities of AT1 receptor mRNA and protein. These additional receptors are functionally coupled, resulting in a stronger response to stimulation with angiotensin II. However, the expression level of AT1 receptor mRNA in diabetic myocardium was downregulated by RAS inhibition with AT1 receptor blockers or ACE inhibitors. Our results clearly show that AT1 receptor density in myocardium of type 2 diabetic patients is dynamic, depending on the level of hyperglycaemic control and the activity of RAS. This suggests that some of the pathophysiological changes in diabetes may be due to receptor regulation. This could at least in part explain the strong therapeutic benefit of RAS inhibition for patients with type 2 diabetes, as evidenced in several large clinical trials.

Acknowledgements We give our special thanks to all colleagues of the Department of Cardio-thoracic Surgery at the University of Cologne (E. R. de Vivie and Th. Wahlers) for providing the myocardial tissue. We thank K. Rösler and E. Köroglu for their excellent technical assistance. This study was supported by the Cologne Fortune Program/Faculty of Medicine, University of Cologne (44/2005 to H. Reuter). The present study contains part of the doctoral thesis of C. Adam (University of Cologne, in preparation).

Duality of interest None of the authors involved in this study had any duality of interest.

\section{References}

1. Nickenig G, Roling J, Strehlow K, Schnabel P, Böhm M (1998) Insulin induces upregulation of vascular AT1 receptor gene expression by posttranscriptional mechanisms. Circulation 98:2453-2460

2. Stenina OI (2005) Regulation of vascular genes by glucose. Curr Pharm Des 11:2367-2381

3. Weir MR, Dzau VJ (1999) The renin-angiotensin-aldosterone system: a specific target for hypertension management. Am J Hypertens 12:205S-213S

4. Nickenig G, Harrison DG (2002) The AT(1)-type angiotensin receptor in oxidative stress and atherogenesis: part I: oxidative stress and atherogenesis. Circulation 105:393-396 
5. Beckman JA, Creager MA, Libby P (2002) Diabetes and atherosclerosis: epidemiology, pathophysiology, and management. JAMA 287:2570-2581

6. Lindholm LH, Ibsen H, Dahlöf B et al (2002) Cardiovascular morbidity and mortality in patients with diabetes in the Losartan Intervention For Endpoint reduction in hypertension study (LIFE): a randomised trial against atenolol. Lancet 359:1004-1010

7. HOPE Investigators (2000) Effects of ramipril on cardiovascular and microvascular outcomes in people with diabetes mellitus: results of the HOPE study and MICRO-HOPE substudy. Lancet 355:253-259

8. Eurich DT, Majumdar SR, Tsuyuki RT, Johnson JA (2004) Reduced mortality associated with the use of ACE inhibitors in patients with type 2 diabetes. Diabetes Care 27:1330-1334

9. Hansson L, Lindholm LH, Niskanen L et al (1999) Effect of angiotensin-converting-enzyme inhibition compared with conventional therapy on cardiovascular morbidity and mortality in hypertension: the Captopril Prevention Project (CAPPP) randomised trial. Lancet 353:611-616

10. Reuter H, Zobel C, Brixius K, Bölck B, Schwinger RH (1999) The force-frequency relationship is dependent on $\mathrm{Ca}(2+)$-influx via L-type- and SR-Ca(2+)-channels in human heart. Basic Res Cardiol 94:159-170

11. Chomczynski P, Sacchi N (1987) Single-step method of RNA isolation by acid guanidinium thiocyanate-phenol-chloroform extraction. Anal Biochem 162:156-159

12. Heid CA, Stevens J, Livak KJ, Williams PM (1996) Real time quantitative PCR. Genome Res 6:986-994

13. Kannel WB, McGee DL (1979) Diabetes and cardiovascular disease. The Framingham study. JAMA 241:2035-2038

14. Stamler J, Vaccaro O, Neaton JD, Wentworth D (1993) Diabetes, other risk factors, and 12-yr cardiovascular mortality for men screened in the Multiple Risk Factor Intervention Trial. Diabetes Care 16:434-444

15. Koch-Weser J (1965) Nature of the inotropic action of angiotensin on ventricular myocardium. Circ Res 16:230-237

16. Baker KM, Aceto JA (1989) Characterization of avian angiotensin II cardiac receptors: coupling to mechanical activity and phosphoinositide metabolism. J Mol Cell Cardiol 21:375-382

17. Holubarsch C, Hasenfuss G, Schmidt-Schweda S et al (1993) Angiotensin I and II exert inotropic effects in atrial but not in ventricular human myocardium. An in vitro study under physiological experimental conditions. Circulation 88:1228-1237

18. Petroff MG, Aiello EA, Palomeque J, Salas MA, Mattiazzi A (2000) Subcellular mechanisms of the positive inotropic effect of angiotensin II in cat myocardium. J Physiol 529:189-203

19. Salas MA, Vila-Petroff MG, Palomeque J, Aiello EA, Mattiazzi A (2001) Positive inotropic and negative lusitropic effect of angiotensin II: intracellular mechanisms and second messengers. J Mol Cell Cardiol 33:1957-1971

20. Katz AM (1990) Angiotensin II: hemodynamic regulator or growth factor? J Mol Cell Cardiol 22:739-747

21. Weber KT, Sun Y, Guarda E (1994) Structural remodeling in hypertensive heart disease and the role of hormones. Hypertension 23:869-877

22. Marchant C, Brown L, Sernia C (1993) Renin-angiotensin system in thyroid dysfunction in rats. J Cardiovasc Pharmacol 22:449-455
23. Meggs LG, Coupet J, Huang H et al (1993) Regulation of angiotensin II receptors on ventricular myocytes after myocardial infarction in rats. Circ Res 72:1149-1162

24. Brown L, Sernia C (1994) Angiotensin receptors in cardiovascular diseases. Clin Exp Pharmacol Physiol 21:811-818

25. Jäger H, Wozniak G, Akinturk IH, Hehrlein FW, Scheiner-Bobis G (2001) Expression of sodium pump isoforms and other sodium or calcium ion transporters in the heart of hypertensive patients. Biochim Biophys Acta 1513:149-159

26. Liao JK (2003) Role of statin pleiotropism in acute coronary syndromes and stroke. Int J Clin Pract Suppl:51-57

27. Lowes BD, Gilbert EM, Abraham WT et al (2002) Myocardial gene expression in dilated cardiomyopathy treated with betablocking agents. N Engl J Med 346:1357-1365

28. Murphy TJ, Alexander RW, Griendling KK, Runge MS, Bernstein KE (1991) Isolation of a cDNA encoding the vascular type-1 angiotensin II receptor. Nature 351:233-236

29. Sodhi CP, Kanwar YS, Sahai A (2003) Hypoxia and high glucose upregulate AT1 receptor expression and potentiate ANG IIinduced proliferation in VSM cells. Am J Physiol Heart Circ Physiol 284:H846-H852

30. Sechi LA, Griffin CA, Schambelan M (1994) The cardiac reninangiotensin system in SZT-induced diabetes. Diabetes 43:11791184

31. Brown L, Wall D, Marchant C, Sernia C (1997) Tissue-specific changes in angiotensin II receptors in streptozotocin-diabetic rats. J Endocrinol 154:355-362

32. Wilkes BM (1987) Reduced glomerular angiotensin II receptor density in diabetes mellitus in the rat: time course and mechanism. Endocrinology 120:1291-1298

33. Anderson S, Jung FF, Ingelfinger JR (1993) Renal reninangiotensin system in diabetes: functional, immunohistochemical, and molecular biological correlations. Am J Physiol 265:F477F486

34. Price DA, Porter LE, Gordon M et al (1999) The paradox of the low-renin state in diabetic nephropathy. J Am Soc Nephrol 10:2382-2391

35. Lassegue B, Alexander RW, Nickenig G, Clark M, Murphy TJ, Griendling KK (1995) Angiotensin II down-regulates the vascular smooth muscle AT1 receptor by transcriptional and post-transcriptional mechanisms: evidence for homologous and heterologous regulation. Mol Pharmacol 48:601-609

36. Nickenig G, Murphy TJ (1996) Enhanced angiotensin receptor type $1 \mathrm{mRNA}$ degradation and induction of polyribosomal mRNA binding proteins by angiotensin II in vascular smooth muscle cells. Mol Pharmacol 50:743-751

37. Makita N, Iwai N, Inagami T, Badr KF (1992) Two distinct pathways in the down-regulation of type-1 angiotension II receptor gene in rat glomerular mesangial cells. Biochem Biophys Res Commun 185:142-146

38. Suzuki J, Matsubara H, Urakami M, Inada M (1993) Rat angiotensin II (type 1A) receptor mRNA regulation and subtype expression in myocardial growth and hypertrophy. Circ Res 73:439-447

39. Iwai N, Yamano $\mathrm{Y}$, Chaki $\mathrm{S}$ et al (1991) Rat angiotensin II receptor: cDNA sequence and regulation of the gene expression. Biochem Biophys Res Commun 177:299-304 